\title{
IMPROVING MEAT QUALITY THROUGH NATURAL ANTIOXIDANTS
}

\author{
Valeria Velasco $^{1 *}$, and Pamela Williams ${ }^{1}$
}

\begin{abstract}
Nowadays, consumers are demanding more natural foods, obliging the industry to include natural antioxidants in foods. Natural antioxidants have been used instead of synthetic antioxidants to retard lipid oxidation in foods to improve their quality and nutritional value. This review discusses some aspects of recent research on antioxidant activity of plant extracts and natural compounds to improve meat quality. Many herbs, spices, and their extracts have been reported as having high antioxidant capacity, such as some plants of the Lamiaceae family, e.g., oregano (Origanum vulgare L.), rosemary (Rosmarinus officinalis L.), and sage (Salvia officinalis L.). The antioxidant activity of these plants is attributed to their phenolic compound content, which includes volatile compounds also known as essential oils. Several factors that cause some differences on the antioxidant activity of plant extracts include: type of solvent used during extraction, measurement method, and number of samples. Some studies have demonstrated that shelf-life and meat quality can be improved by using natural antioxidants in some stages of meat production. The main effects of these compounds are reducing microbial growth and lipid oxidation during storage. Nevertheless, more research is needed to determine antimicrobial activity of natural antioxidants in meat during storage, identify the main metabolic pathway of these compounds, and its effect on other meat quality parameters.
\end{abstract}

Key words: antioxidant activity, essential oils, phenolic compounds, meat quality.

$\mathrm{T}$ he increasing preference for natural foods has obliged the food industry to include natural antioxidants in various products to delay oxidative degradation of lipids, improve quality and nutritional value of foods, and replace synthetic antioxidants (Fasseas et al., 2007; Wojdylo et al., 2007; Camo et al., 2008). Including antioxidants in the diet has beneficial effects on human health because they protect the biologically important cellular components, such as DNA, proteins, and membrane lipids, from reactive oxygen species (ROS) attacks (Su et al., 2007). Synthetic antioxidants have been used to retard or minimize oxidative deterioration of foods, such as butylated hydroxyanisole (BHA), butylated hydroxytoluene (BHT), and tertiary butyl hydroquinone (TBHQ) (Fasseas et al., 2007). Recently, consumers have rejected synthetic antioxidants because of their carcinogenicity (Altmann et al., 1986; Van Esch, 1986). The advantages of natural antioxidants in foods are high consumer acceptance and

${ }^{1}$ Universidad de Concepción, Facultad de Agronomía, Av. Vicente Méndez 595, Chillán, Chile.

*Corresponding author (vvelasco@udec.cl).

Received: 21 June 2010.

Accepted: 23 January 2011. their safe use. The disadvantages are their higher cost and lower effectiveness (Fasseas et al., 2007).

Many herbs, spices, and their extracts have been added in a variety of foods to improve their sensory characteristics and extend shelf-life (Shahidi et al., 1992). Herbs of the Lamiaceae family, mainly oregano (Origanum vulgare L.), rosemary (Rosmarinus officinalis L.), and sage (Salvia officinalis L.), have been reported as having significant antioxidant capacity (Shan et al., 2005; Wojdylo et al., 2007).

The short shelf-life of refrigerated packed meat makes its commercialization more difficult. Some studies have demonstrated that meat shelf-life and quality can be improved by natural antioxidants added in the preslaughter and post-slaughter stages. That is, incorporating natural antioxidants in animal diets, onto the meat surface, or active packaging.

Some authors have reported the effectiveness of rosemary and oregano extracts to reduce lipid oxidation (Djenane et al., 2002; 2003; Fasseas et al., 2007; Camo et al., 2008), color loss, and microbial growth (Djenane et al., 2002; 2003; Camo et al., 2008; Zinoviadou et al., 2009) in some types of meats. 
The aim of this review was to discuss some aspects of recent research on antioxidant activity of plant extracts and natural compounds and their use to improve meat quality.

\section{DISCUSSION}

\section{Definition and chemistry of natural antioxidants}

Natural antioxidants are various substances with different chemical characteristics, which are widely present in plants. Antioxidants retard or inhibit oxidation of other substances by inhibiting the initiation or propagation of oxidizing chain reactions (Velioglu et al., 1998). Consequently, natural antioxidants can protect the biologically important cellular components from oxidative processes caused by reactive oxygen species (ROS) (Su et al., 2007).

The total antioxidant capacity of fruit and vegetable extracts reflects concentrations of ascorbic acid (vitamin C), alpha-tocopherol (vitamin E), beta-carotene (vitamin A precursor), various flavonoids, and other phenolic compounds (Pennington and Fisher, 2009).

Some authors have demonstrated the high antioxidant activity of $\alpha$-tocopherol, ascorbic acid, and their high radical scavenging abilities (Kulisic et al., 2004). Furthermore, some synergistic effects among ascorbic acid, $\alpha$-tocopherol, and $\beta$-carotene have been reported against oxidation (Yeum et al., 2009). In addition, phenolic compounds have a high antioxidant activity through three mechanisms: free-radical scavenging activity (Zheng et al., 2009), transition-metal-chelating activity (Andjelković et al., 2006), and/or singlet-oxygenquenching capacity (Mukai et al., 2005).

The antioxidant capacity of vitamins and phenolic compounds measured by different methods indicates that some natural antioxidants have a high antioxidant activity, such as gallic acid, cyanidin, quercetin, catechin, thymol, and carvacrol (Table 1). Measurements are generally based on Trolox equivalents, which are a water-soluble derivative of vitamin $\mathrm{E}$ used as a standard.

Table 2 shows the main phenolic compounds identified in plant extracts, such as phenolic acids (e.g., $p$-coumaric acid, caffeic acid, rosmarinic acid, and gallic acid), phenolic diterpenes (e.g., carnosic acid and epirosmanol), flavonoids (e.g., catechin and kaempferol), and volatile oils (e.g., aromatic compounds) (Shan et al., 2005).

Table 1. Antioxidant capacity of vitamins and phenolic compounds.

\begin{tabular}{|c|c|c|c|}
\hline \multirow[b]{2}{*}{ Compound } & \multicolumn{3}{|c|}{ Antioxidant capacity $\left(\mu \mathrm{mol}\right.$ TE $\left.\mathrm{mmol}^{-1}\right)$} \\
\hline & TEAC & DPPH & ORAC \\
\hline \multicolumn{4}{|l|}{ Vitamins } \\
\hline \multirow[t]{3}{*}{ Ascorbic acid } & $1000^{(3)}$ & $8.6 \times 10^{-3 *(1)}$ & $500-1000^{(3)}$ \\
\hline & & $500^{(3)} 4.4 \times 10^{-3 *(1)}$ & \\
\hline & & $3.8 \times 10^{-3 *(2)} 2.13 \times 10^{-3 *(4)}$ & \\
\hline \multicolumn{4}{|l|}{ Flavonols } \\
\hline Kaempferol & $500-1000^{(3)}$ & $1000^{(3)}$ & $6000^{(3)}$ \\
\hline Quercetin & $2000^{(3)}$ & $1000^{(3)}$ & $4000^{(3)}$ \\
\hline \multicolumn{4}{|l|}{ Anthocyanins } \\
\hline Cyanidin & $2000^{(3)}$ & $500-1000^{(3)}$ & $4500^{(3)}$ \\
\hline \multicolumn{4}{|l|}{ Flavanons } \\
\hline Naringenin & $0^{(3)}$ & $0^{(3)}$ & $5500^{(3)}$ \\
\hline \multicolumn{4}{|l|}{ Flavan-3-ols } \\
\hline Catechin & $1500^{(3)}$ & $2000^{(3)}$ & $7500-8000^{(3)}$ \\
\hline \multicolumn{4}{|l|}{ Phenolic acids } \\
\hline Chlorogenic acid & $1500^{(3)}$ & $1000^{(3)}$ & $5000^{(3)}$ \\
\hline Gallic acid & $2500^{(3)}$ & $1000^{(3)} 0.8 \times 10^{-3 *(4)}$ & $1000^{(3)}$ \\
\hline \multicolumn{4}{|l|}{ Volatile compound } \\
\hline Thymol & & $0.5^{*(1)} 0.16^{*(2)}$ & \\
\hline Carvacrol & & $0.4^{*(1)} 0.25^{*(2)}$ & \\
\hline
\end{tabular}

TE: Trolox equivalents. TEAC: Trolox equivalent antioxidant capacity. DPPH: Scavenging of radical 2,2-diphenyl-1-picryhydrazyl. ORAC: Oxygen radical absorbance capacity.

* Concentration $\left(\mathrm{g} \mathrm{L}^{-1}\right)$ for $50 \%$ inhibition.

${ }^{(1)}$ Kulisic et al. (2004); ${ }^{(2)}$ Tepe et al. (2005b); ${ }^{(3)}$ Tabart et al. (2009); ${ }^{(4)}$ Zheng et al. (2009). 


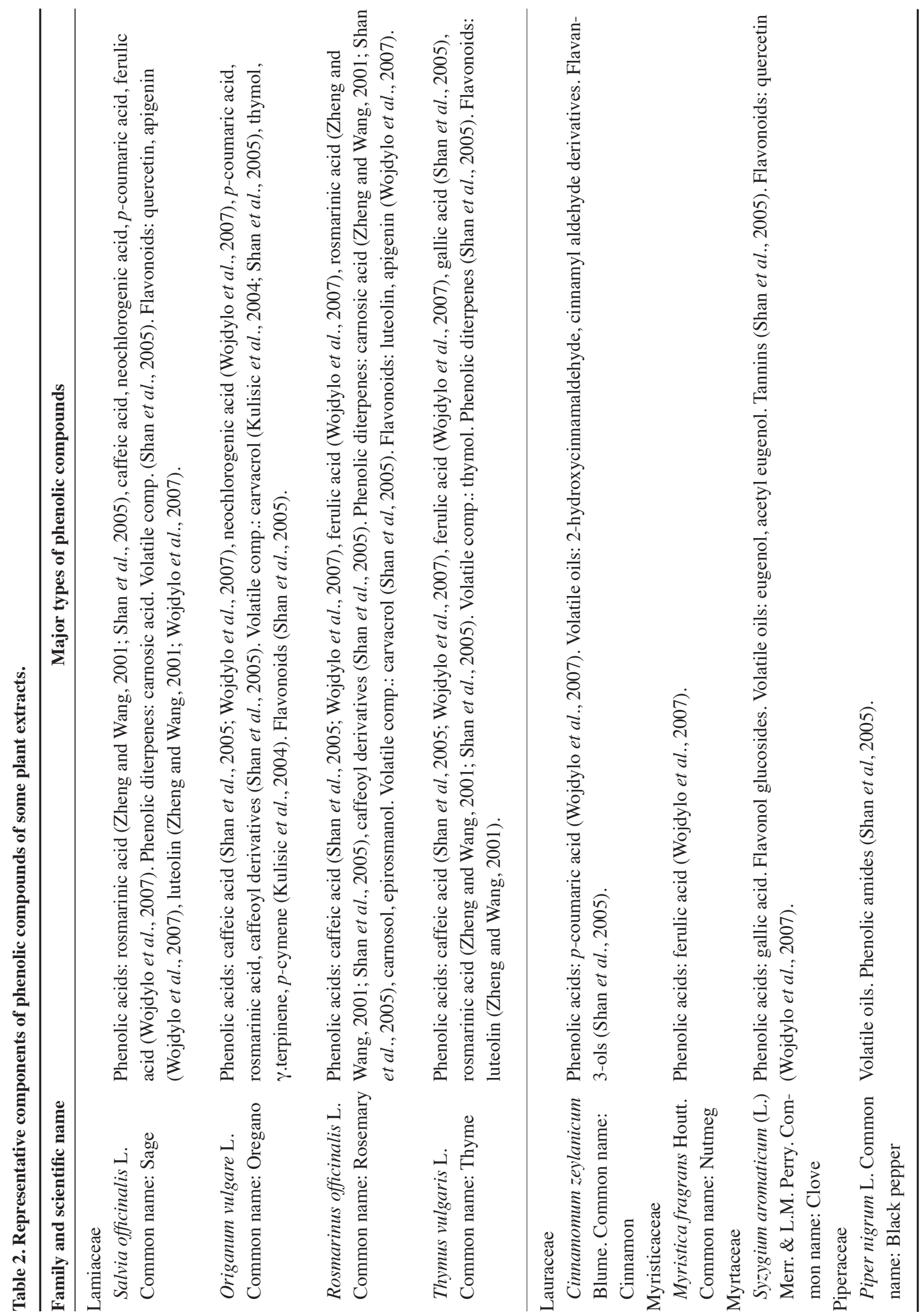


Phenolic volatile compounds, also known as essential oils, are the main active ingredients in most herbs, e.g., menthol (in mint Mentha canadensis L.), carvacrol (in oregano and rosemary), thymol (in thyme Thymus vulgaris L.), and eugenol (in clove Syzygium aromaticum (L.) Merr. \& L.M. Perry)(Shan et al., 2005). The main components of essential oils are terpenoids, specifically monoterpenes $(\mathrm{C} 10)$ and sesquiterpenes (C15), as well as a variety of low molecular weight compounds (Dorman and Deans, 2000; Flamini et al., 2007). Bampidis et al. (2005) reported that the major oregano essential oil compounds were carvacrol, thymol, $\gamma$-terpinene, and $p$-cymene. On the other hand, Kulisic et al. (2004) obtained 35\% thymol and 32\% carvacrol, which were the main oregano essential oil constituents.

Some authors have demonstrated antioxidant and antimicrobial activities of essential oils (Helander et al., 1998; Cosentino et al., 1999; Burt, 2004; Tepe et al., 2005a; 2005b; Hussain et al., 2008). Essential oil antibacterial properties are attributed to their phenolic compounds (Cosentino et al., 1999; Rota et al., 2008). The presence of hydroxyl groups and their relative position in the phenolic ring enable antimicrobial activity and can explain the high antimicrobial activity of carvacrol compared to other plant phenolic compounds (Dorman and Deans, 2000; Zinoviadou et al., 2009). Dormans and Deans (2000) indicate that essential oil antibacterial properties are associated with their lipophilic character and functional group. Thus, essential oils interact with processes associated with the phospholipid bilayer, including electron transport, ion gradients, protein translocation, phosphorylation, and other enzyme-dependent reactions (Dorman and Deans, 2000; Burt, 2004), resulting in an increase of bacterial cell membrane permeability (Lambert et al., 2001). Burt (2004) suggested that Gram (-) bacteria are more resistant to essential oil compound antibacterial properties than Gram (+) bacteria because they have an external lipopolysaccharide wall surrounding the peptidoglycan cell wall, which limits access of these compounds. However, essential oil hydrophobic compounds are able to achieve periplasm of Gram (-) bacteria through proteins located in the outer membrane (Helander et al., 1998; Lambert et al., 2001). Rota et al. (2008) suggested a synergistic action among phenolic compounds and some terpenic hydrocarbons, alcohols, ketones, and thymol oxygenated derivatives, as well as synergism between carvacrol and its precursor $p$-cymene. On the other hand, Cosentino et al. (1999) noted an antagonist effect of high $p$-cymene content on antimicrobial phenol action.

Many herbs, spices, and their extracts are known to possess antioxidant effects (Zheng and Wang, 2001; Shan et al., 2005), especially clove (Myrtaceae), cinnamon (Cinnamomum zeylanicum Blume in Lauraceae), and oregano (Lamiaceae) (Shan et al., 2005). Some authors have attributed the antioxidant activity of these plants to their phenolic compound content, resulting in a positive linear correlation between them (Velioglu et al., 1998; Kähkönen et al., 1999; Zheng and Wang, 2001; Shan et al., 2005). Antioxidant activity, measured by three different methods, and total phenolic content of some plant extracts are shown in Table 3. Species with a strong antioxidant capacity have high phenolic content. One example is clove that had the highest antioxidant capacity as measured by three methods and was related to the highest phenolic content. Zheng and Wang (2001) found the strongest antioxidant activity in Mexican oregano $(92.18 \mu \mathrm{mol}$ of Trolox equivalents (TE) $\mathrm{g}^{-1}$ fresh weight) and the highest phenolic content (17.51 mg gallic acid equivalents (GAE) $\mathrm{g}^{-1}$ fresh weight). However, some studies did not obtain the same relationship between antioxidant capacity and total phenolic content in some species (Kähkönen et al., 1999; Wojdylo et al., 2007). For example, high antioxidant activity of apple (Malus domestica Borkh.) extracts with low total phenolic content may be due to the presence of other compounds that might interfere with the determination methods (Kähkönen et al., 1999). In addition to phenolic compounds, some species have shown a positive relationship between antioxidant activity and vitamin $\mathrm{C}$, vitamin $\mathrm{E}$, and beta-carotene content. Polyphenols and vitamin $\mathrm{C}$ are the major contributors of the high antioxidant activity of kiwifruits (Actinidia sp.) (Du et al., 2009). The same was detected in Brassica vegetables with carotenoids and Vitamin E responsible for up to $20 \%$ of total antioxidant activity (Podsędek, 2007).

Differences found in some research indicate that other factors can affect the antioxidant activity of some plants (Velioglu et al., 1998), which can be related to number of samples, small differences between the highest and lowest values, method used to extract antioxidant compounds, and method used to measure antioxidant capacity (Kähkönen et al., 1999; Kulisic et al., 2004; Shan et al., 2005; Fasseas et al., 2007; Su et al., 2007; Wojdylo et al., 2007; Karadag et al., 2009; Tabart et al., 2009).

\section{Some experiences in meat quality}

Meat quality can be improved by incorporating natural antioxidants to animal diets, adding these compounds onto the meat surface, or using active packaging. Among the positive effects of natural antioxidants on meat characteristics are retarding lipid oxidation (Djenane et al., 2002; 2003; Fasseas et al., 2007; Camo et al., 2008), color loss, and microbial growth (Djenane et al., 2002; 2003; Camo et al., 2008; Zinoviadou et al., 2009). 


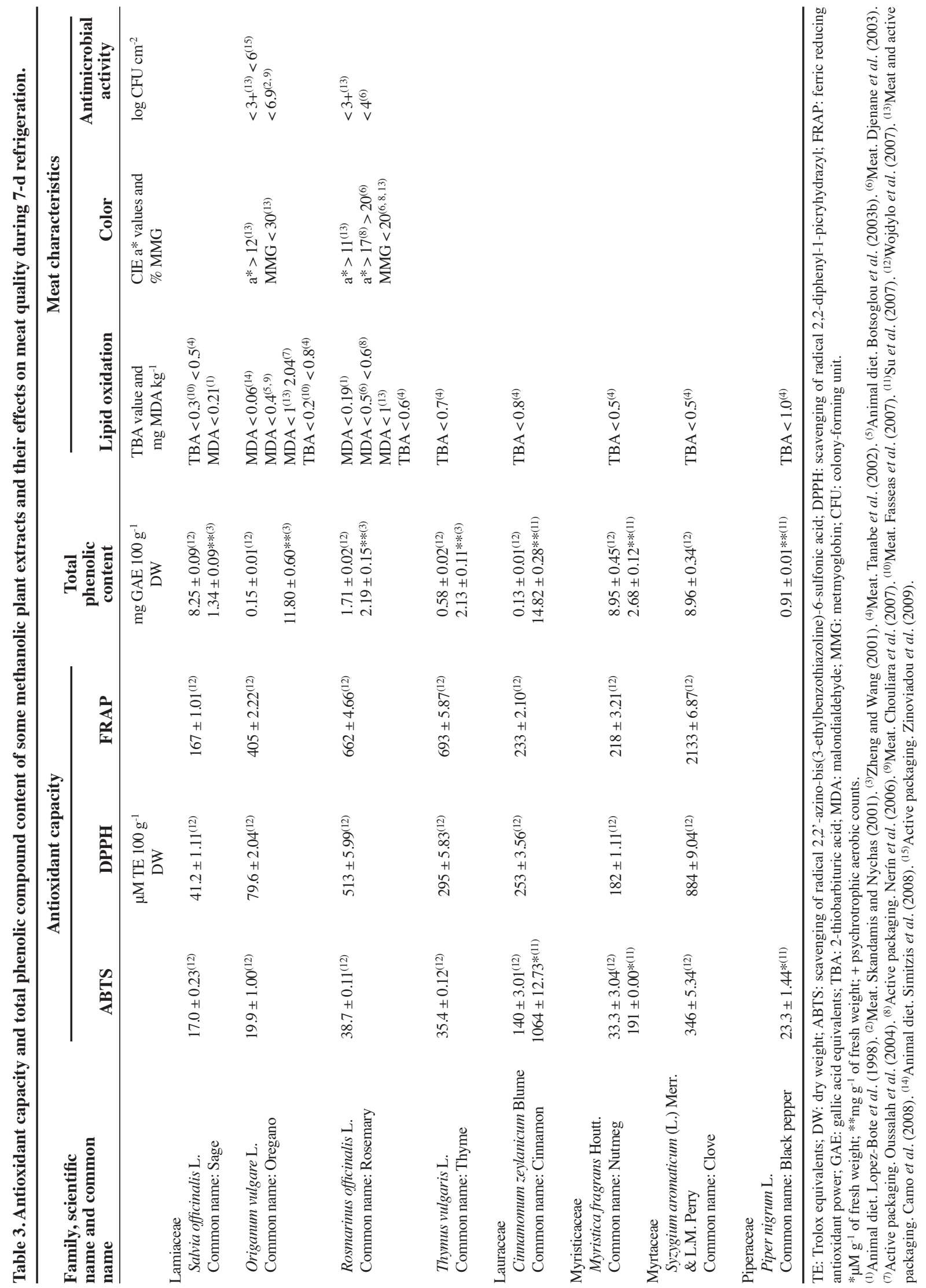


Some authors have reported that natural antioxidants have no effect on sensory characteristics of meat. Chaves et al. (2008) did not detect any effect of essential oil compounds (carvacrol and cinnamaldehyde), added to the diet of growing lambs, on the sensory characteristics of sirloins. The same was observed in pork where different essential oils were included in the diet of pigs (Janz et al., 2007). The only evidence of the effect of natural antioxidants on inhibiting off-odor formation and discoloration of meat is active packaging (Djenane et al., 2003; Nerín et al., 2006; Camo et al., 2008).

Some plant extracts have had a positive effect on lipid oxidation by reducing 2-thiobarbituric acid (TBA) or malondialdehyde (MDA) formation on different types of meats during refrigeration storage (Table 3). Tanabe et al. (2002) reported that adding methanolic extracts of 22 selected herbs and spices decrease lipid oxidation in pork with sansho (Zanthoxylum piperitum L.) extracts, sage, and ginger (Zingiber officinale Rosc.) having the greatest effect. Oregano and sage essential oils added to beef and pork meat (Fasseas et al., 2007), and a rosemary and vitamin C solution sprayed onto the surface (Djenane et al., 2003) reduce oxidation during refrigeration. In addition, dietary incorporation of oregano, rosemary, and sage essential oils can retard lipid oxidation (MDA formation) in meat during refrigerated and frozen storage (Lopez-Bote et al., 1998; Botsoglou et al., 2002; 2003a; 2003b; Simitzis et al., 2008). Botsoglou et al. (2003a) reported that $\alpha$-tocopheryl acetate supplementation was more effective than dietary incorporation of oregano essential oil to extend lipid stability of chicken meat in frozen storage. Moreover, there is a synergistic effect between dietary essential oil and $\alpha$-tocopheryl acetate supplementation in retarding lipid oxidation in raw and cooked turkey during refrigeration (Botsoglou et al., 2003b). Lopez-Bote et al. (1998) observed an additional effect on meat cooked at $70{ }^{\circ} \mathrm{C}$, which came from broilers fed on diets containing rosemary and sage extracts, during refrigerated storage for up to $4 \mathrm{~d}$. The strongest effect of dietary oregano essential oil supplementation to reduce lipid oxidation has been found at levels of 100 $\mathrm{mg} \mathrm{kg}^{-1}$ feed in chicken meat (Botsoglou et al., 2002; Botsoglou et al., 2003a) and $200 \mathrm{mg} \mathrm{kg}^{-1}$ feed in turkey meat (Botsoglou et al., 2003b). Janz et al. (2007) only noted a reduction of lipid oxidation in oregano essential oil fed to pigs when compared with other essential oil dietary inclusion treatments (rosemary, garlic Allium sativum L., or ginger). Lower MDA formation in dietary oregano essential oil treatments are probably the result of the presence of oregano antioxidant compounds, which might be absorbed into the circulatory system after ingestion, distributed, and retained in muscle and other tissues (Botsoglou et al., 2003b; Simitzis et al., 2008).
Other plant extracts such as grape (Vitis vinifera L.) seed and bearberry (Arctostaphylos uva-ursi L.) applied onto the meat surface have been effective in decreasing lipid oxidation in raw and cooked pork patties (Carpenter et $a l ., 2007)$. The same was obtained by adding tea catechins to beef patties, but with no effect on chicken meat patties (Mitsumoto et al., 2005).

Some studies have used vitamin E ( $\alpha$-tocopherol) in both direct application onto meat and animal diet supplementation to extend lipid stability of fresh beef during storage (Arnold et al., 1993; Eikelenboom et al., 2000; O'Grady et al., 2000). Mitsumoto et al. (1993) reported that the post-mortem addition of vitamin $\mathrm{E}$ in beef was less effective in retarding lipid oxidation than dietary supplementation. Djenane et al. (2002) concluded that surface application of vitamin C, taurine, rosemary, vitamin $\mathrm{E}$, and combinations of the last three with vitamin $\mathrm{C}$ have a positive effect on oxidative stability of beef steaks packaged in a modified atmosphere.

Meat color has been reported as the most important factor when consumers assess meat quality since they relate color to freshness. However, color does not correspond to differences in eating satisfaction (Carpenter et al., 2001). Changes in meat color are due to oxidation of red oxymyoglobin to metmyoglobin (MMG), which give meat an unattractive brown color (Nerín et al., 2006). Some reports demonstrate that natural antioxidants can retard meat color loss by extending the red color $\left(\mathrm{a}^{*}\right)$ and delaying MMG formation (Table 3). One example of dietary natural antioxidants affecting meat color is the higher color parameters ( $\mathrm{a}^{*}$ and yellowness $\mathrm{b}^{*}$ ) of meat from lambs fed with oregano essential oil supplementation ( $1 \mathrm{~mL}$ oregano essential oil $\mathrm{kg}^{-1}$ ) (Simitzis et al., 2008). Another example is the reduction of MMG formation and intense red color obtained in fresh beef steaks whose surface was sprayed with a rosemary and ascorbic acid solution during refrigeration (Djenane et al., 2003). Carpenter et al. (2007) noted that the color parameters (lightness $\mathrm{L}^{*}, \mathrm{~b}^{*}$, and $\mathrm{a}^{*}$ ) of raw pork patties did not vary by adding grape seed and bearberry extracts. The same results were obtained for fresh chicken breast meat (Chouliara et al., 2007).

Some authors have demonstrated the antioxidant effect of some vitamins to delay color loss in meat during storage. One of these vitamins, vitamin E ( $\alpha$-tocopherol), has been used to improve myoglobin stability of fresh beef during storage by supplementing animal diets with at least $1300 \mathrm{IU} \mathrm{d}^{-1}$ (Arnold et al., 1993) or $2025 \mathrm{mg}$ of vitamin E per day (Eikelenboom et al., 2000). A vitamin C solution of sodium ascorbate (5\% of cut weight containing at least $4 \%$ of sodium ascorbate) injected in beef was also effective in improving color stability and extending the meat's retail display life (Wheeler et al., 1996). 
Some authors reported that plant extracts with antimicrobial properties can be used to increase refrigerated meat shelf-life (Skandamis et al., 2002; Djenane et al., 2003; Chouliara et al., 2007). Table 3 shows some values of colony-forming units obtained with some plant extracts applied onto the meat surface. Eugenol, clove, oregano, and thyme extracts applied on meat were reported to be effective against L. monocytogenes, A. hydrophila, and autochthonous spoilage flora at higher concentrations than those required by in vitro assays (Hao et al., 1998a; 1998b; Skandamis and Nychas, 2001). Antibacterial activity of natural antioxidants has been determined through in vitro assays against Escherichia coli 0157:H7, Salmonella typhimurium (Helander et al., 1998; Elgayyar et al., 2001), Staphylococcus aureus, and Pseudomonas aeruginosa (Elgayyar et al., 2001; Lambert et al., 2001).

The antimicrobial properties of essential oils extracted from plants used against a wide range of microorganisms (Dean and Ritchie, 1987; Sivropoulou et al., 1996; Chao et al., 2000) have been considered as an alternative to antibiotics in livestock. Therefore, essential oils are promising as feed additives to improve feed efficiency and control the spread of pathogens in livestock (Benchaar et al., 2008).

Nowadays, active packaging has been intensely developed due to recent contamination outbreaks associated with meat products (Coma, 2008). Table 3 shows some effects of natural antioxidants included in active films. The effectiveness of antimicrobial compounds might be higher when they are incorporated in an active film applied to the food surface than if directly applied to the food surface by spraying or dipping (Coma, 2008; Zinoviadou et al., 2009). Oregano-based films have been effective against bacterial growth in meat. For example, active films containing oregano essential oil can reduce the growth of total flora and pseudomonas, thus inhibiting the growth of lactic acid bacteria in beef (Zinoviadou et al., 2009). Moreover, oregano-based films were effective against Salmonella typhimurium and E. coli $\mathrm{O} 157: \mathrm{H} 7$ inoculated in beef muscle slices (Oussalah et al., 2006). Thus, beef shelf-life can be increased by 2 when employing active films containing $1.5 \%$ oregano oil (w/w) (Zinoviadou et al., 2009). Skandamis and Nychas (2001) informed that oregano essential oil compounds affected both growth and metabolic activity (glucose and lactate consumption) of meat microorganisms during storage. In addition, meat packed in active film containing natural antioxidants exhibits higher antioxidant activity than meat packed in films without antioxidants (Nerín et al., 2006; Camo et al., 2008). Oregano-based films stabilized lipid oxidation in beef muscle slices during $7 \mathrm{~d}$ when stored at $4{ }^{\circ} \mathrm{C}$ (Oussalah et al., 2004). There are few studies about the effect of active film containing natural antioxidants on meat color. Camo $e t$ al. (2008) reported a greater effect of oregano active film against color loss and MMG formation in lamb meat than rosemary active packaging. The latter was less effective than directly adding rosemary extract onto the meat surface. Values of a* were above 10 and MMG formation was around $40 \%$ after $13 \mathrm{~d}$ of refrigeration using oregano active films and directly adding rosemary extract onto the meat surface. Zinoviadou et al. (2009) reported smaller changes in total color difference $(\Delta \mathrm{E})$ and saturation difference ( $\Delta$ chroma) in beef cuts wrapped in films with different levels of oregano oil $(0.5 \%, 1.0 \%$, and $1.5 \% \mathrm{w} / \mathrm{w})$ during refrigeration and resulted in better color retention due to oxymyoglobin stabilization .

\section{CONCLUSIONS}

Some plant extracts are an excellent source of natural antioxidants that can improve meat shelf-life and quality mainly by retarding lipid oxidation and microbial growth. The effect of oregano essential oil on meat quality has been studied the most, whereas there is less information about other plants.

Antimicrobial activity of spices and herbs has been extensively studied. However, most of the research was done in in vitro assays using microbiological media rather than actual foods. Further research is needed to determine their effect on bacterial growth in raw and cooked meats during storage. Active packaging containing natural antioxidants is a promising tool in this field.

There is some evidence that dietary essential oils can improve meat quality. Since bioavailability of essential oils in meat cannot be directly demonstrated, more research is needed to identify the main metabolic pathway of these compounds and the key essential oil antioxidant compounds deposited in meat.

Further research is needed to determine the effect of natural antioxidants on other meat quality characteristics.

\section{RESUMEN}

Mejoramiento de la calidad de carne utilizando antioxidantes naturales. Actualmente los consumidores están demandando alimentos más naturales, lo cual ha causado el interés de la industria de incluir antioxidantes naturales en los alimentos para retardar la oxidación de los lípidos, mejorar su calidad y valor nutricional, reemplazando los antioxidantes sintéticos. En esta revisión se discuten algunos aspectos de las investigaciones más recientes acerca de la actividad antioxidante de extractos vegetales y compuestos naturales y su uso para mejorar la calidad de carne. Se ha encontrado que muchas plantas y sus extractos tienen actividad antioxidante, tales como orégano (Origanum vulgare L.), romero (Rosmarinus 
officinalis L.) y salvia (Salvia officinalis L.). La actividad antioxidante de estas plantas se atribuye a su contenido de compuestos fenólicos, los cuales incluyen compuestos volátiles llamados aceites esenciales. Algunos factores podrían causar diferencias en la actividad antioxidante de extractos de plantas, tales como: tipo de solvente utilizadoen la extracción, método utilizado en las mediciones, número de muestras, entre otros. Algunos estudios han demostrado que la vida útil y la calidad de carne pueden mejorarse a través del uso de antioxidantes naturales en algunas etapas de la producción de carne. Los principales efectos de estos compuestos son la reducción del crecimiento microbiano y oxidación de lípidos durante el almacenamiento. Sin embargo, se necesita mayor investigación para determinar la actividad antimicrobiana de los antioxidantes naturales en la carne durante el almacenamiento e identificar la principal vía metabólica de estos compuestos y su efecto sobre otras características de calidad de carne.

Palabras clave: actividad antioxidante, aceites esenciales, compuestos fenólicos, calidad de carne.

\section{LITERATURE CITED}

Altmann, H.J., W. Grunow, U. Mohr, H.B RichterReichhelm, and P.W. Wester. 1986. Effects of BHA and related phenols on the forestomach of rats. Food Chemistry and Toxicology 24:1183-1188.

Andjelković, M., J. Van Camp, B. De Meulenaer, G. Depaemelaere, C. Socaciu, M. Verloo, and R. Verhe. 2006. Iron-chelation properties of phenolic acids bearing catechol and galloyl groups. Food Chemistry 98:23-31.

Arnold, R.N., K.K. Scheller, S.C. Arp, S.N. Williams, and D.M. Schaefer. 1993. Tissue equilibration and subcellular distribution of vitamin $\mathrm{E}$ relative to myoglobin and lipid oxidation in displayed beef. Journal of Animal Science 71:105-118.

Bampidis, V.A., V. Christodoulou, P. Florou-Paneri, E. Christaki, A.B. Spais, and P.S. Chatzopoulou. 2005. Effect of dietary dried oregano leaves supplementation on performance and carcass characteristics of growing lambs. Animal Feed Science and Technology 121:285-295.

Benchaar, C., S. Calsamiglia, A.V. Chaves, G.R. Fraser, D. Colombatto, T.A. McAllister, and K.A. Beauchemin. 2008. A review of plant-derived essential oils in ruminant nutrition and production. Animal Feed Science and Technology 145:209-228.

Botsoglou, N.A., E. Christaki, D.J. Fletouris, P. FlorouPaneri, and A.B. Spaisa. 2002. The effect of dietary oregano essential oil on lipid oxidation in raw and cooked chicken during refrigerated storage. Meat Science 62:259-265.
Botsoglou, N.A., D.J. Fletouris, P. Florou-Paneri, E. Christaki, and A.B. Spais. 2003a. Inhibition of lipid oxidation in long-term frozen stored chicken meat by dietary oregano essential oil and $\alpha$-tocopheryl acetate supplementation. Food Research International 36:207-213.

Botsoglou, N.A., S.H. Grigoropoulou, E. Botsoglou, A. Govaris, and G. Papageorgiou. 2003b. The effects of dietary oregano essential oil and $\alpha$-tocopheryl acetate on lipid oxidation in raw and cooked turkey during refrigerated storage. Meat Science 65:1193-1200.

Burt, S. 2004. Essential oils: their antibacterial properties and potential applications in foods-a review. International Journal of Food Microbiology 94:223-253.

Camo, J., J.A. Beltrán, and P. Roncalés. 2008. Extension of the display life of lamb with an antioxidant active packaging. Meat Science 80:1086-1091.

Carpenter, C.E., D.P. Cornforth, and D. Whittier. 2001 Consumer preferences for beef color and packaging did not affect eating satisfaction. Meat Science 57:359-363.

Carpenter, R., M.N. O'Grady, Y.C. O'Callaghan, N.M. O'Brien, and J.P. Kerry. 2007. Evaluation of the antioxidant potential of grape seed and bearberry extracts in raw and cooked pork. Meat Science 76:604-610.

Chao, S.C., D.G. Young, and C.J. Oberg. 2000. Screening for inhibitory activity of essential oils on selected bacteria, fungi and viruses. Journal of Essential Oil Research 12:639-649.

Chaves, A.V., K. Stanford, L.L. Gibson, T.A. McAllister, and C. Benchaar. 2008. Effects of carvacrol and cinnamaldehyde on intake, rumen fermentation, growth performance, and carcass characteristics of growing lambs. Animal Feed Science and Technology 145:396-408.

Chouliara, E., A. Karatapanis, I.N. Savvaidis, and M.G. Kontominas. 2007. Combined effect of oregano essential oil and modified atmosphere packaging on shelf-life extension of fresh chicken breast meat, stored at $4{ }^{\circ} \mathrm{C}$. Food Microbiology 24:607-617.

Coma, V. 2008. Bioactive packaging technologies for extended shelf life of meat-based products. Meat Science 78:90-103.

Cosentino, S., C.I.G. Tuberoso, B. Pisano, M. Satta, V. Mascia, E. Arzedi, and F. Palmas. 1999. In-vitro antimicrobial activity and chemical composition of Sardinian Thymus essential oils. Letters of Applied Microbiology 29:130-135.

Dean, S.G., and G. Ritchie. 1987. Antibacterial properties of plant essential oils. International Journal Food Microbiology 5:165-180. 
Djenane, D., A. Sánchez-Escalante, J.A. Beltrán, and P. Roncalés. 2002. Ability of $\alpha$-tocopherol, taurine and rosemary, in combination with vitamin $\mathrm{C}$, to increase the oxidative stability of beef steaks packaged in modified atmosphere. Food Chemistry 76:407-415.

Djenane, D., A. Sánchez-Escalante, J.A. Beltrán, and P. Roncalés. 2003. Extension of the shelf life of beef steaks packaged in a modified atmosphere by treatment with rosemary and displayed under UV-free lighting. Meat Science 64:417-426.

Dorman, H.J.D., and S.G. Deans. 2000. Antimicrobial agents from plants: antibacterial activity of plant volatile oils. Journal of Applied Microbiology 88:308-316.

Du, G., M. Li, F. Ma, and D. Liang. 2009. Antioxidant capacity and the relationship with polyphenol and vitamin $\mathrm{C}$ in Actinidia fruits. Food Chemistry 113:557-562.

Eikelenboom, G., B.A.H. Hoving, I. Kluitman, J.H. Houben, and R.E. Klont. 2000. Effect of dietary vitamin $\mathrm{E}$ supplementation on beef colour stability. Meat Science 54:17-22.

Elgayyar, M., F.A. Draughon, D.A. Golden, and J.R. Mount. 2001. Antimicrobial activity of essential oils from plants against selected pathogenic and saprophytic microorganisms. Journal of Food Protection 64:1019-1024.

Fasseas, M.K., K.C. Mountzouris, P.A. Tarantilis, M. Polissiou, and G. Zervas. 2007. Antioxidant activity in meat treated with oregano and sage essential oils. Food Chemistry 106:1188-1194.

Flamini, G., P.L. Cioni, I. Morelli, and A. Bader. 2007. Essential oils of the aerial parts of three Salvia species from Jordan: Salvia lanigera, S. spinosa and S. syriaca. Food Chemistry 100:732-735.

Hao, Y.Y., R.E. Brackett, and M.P. Doyle. 1998a. Efficacy of plant extracts in inhibiting Aeromonas hydrophila and Listeria monocytogenes in refrigerated, cooked poultry. Food Microbiology 15:367-378.

Hao, Y.Y., R.E. Brackett, and M.P. Doyle. 1998b. Inhibition of Listeria monocytogenes and Aeromonas hydrophila by plant extracts in refrigerated cooked beef. Journal of Food Protection 61:307-312.

Helander, I.M., H.-L. Alakomi, K. Latva-Kala, T. Mattila-Sandholm, I. Pol, E.J. Smid, et al. 1998. Characterization of the action of selected essential oil components on Gram-negative bacteria. Journal of Agriculture and Food Chemistry 46:3590-3595.

Hussain, A.L., F. Anwar, S.T. Hussain Sherazi, and R. Przybylski. 2008. Chemical composition, antioxidant and antimicrobial activities of basil (Ocimum basilicum) essential oils depends on seasonal variations. Food Chemistry 108:986-995.
Janz, J.A.M., P.C.H. Morel, B.H.P. Wilkinson, and R.W. Purchas. 2007. Preliminary investigation of the effects of low-level dietary inclusion of fragrant essential oils and oleoresins on pig performance and pork quality. Meat Science 75:350-355.

Kähkönen, M.P., A.I. Hopia, H.J. Vuorela, J.-P. Rauha, K. Pihlaja, T.S. Kujala, and M. Heinonen. 1999. Antioxidant activity of plant extracts containing phenolic compounds. Journal of Agriculture and Food Chemistry 47:3954-3962.

Karadag, A., B. Ozcelik, and S. Saner. 2009. Review of methods to determine antioxidant capacities. Food Analytical Methods 2:41-60.

Kulisic, T., A. Radonic, V. Katalinic, and M. Milos. 2004. Use of different methods for testing antioxidative activity of oregano essential oil. Food Chemistry 85:633-640.

Lambert, R.J.W., P.N. Skandamis, P.J. Coote, and G.-J.E Nychas. 2001. A study of the minimum inhibitory concentration and mode of action of oregano essential oil, thymol and carvacrol. Journal of Applied Microbiology 91:453-462.

Lopez-Bote, C.J., J.I. Gray, E.A. Gomaa, and C.J. Flegal. 1998. Effect of dietary administration of oil extracts from rosemary and sage on lipid oxidation in broiler meat. British Poultry Science 39:235-240.

Mitsumoto, M., R.N. Arnold, D.M. Schaefer, and R.G. Cassens. 1993. Dietary versus postmortem supplementation of vitamin $\mathrm{E}$ on pigment and lipid stability in ground beef. Journal of Animal Science 71:1812-1816.

Mitsumoto, M., M.N. O'Grady, J.P. Kerry, and D.J. Buckley. 2005. Addition of tea catechins and vitamin $\mathrm{C}$ on sensory evaluation, colour and lipid stability during chilled storage in cooked or raw beef and chicken patties. Meat Science 69:773-779.

Mukai, K., S. Nagai, and K. Ohara. 2005. Kinetic study of the quenching reaction of singlet oxygen by tea catechins in ethanol solution. Free Radical Biology and Medicine 39:752-761.

Nerín, C., L. Tovar, D. Djenane, J. Camo, J. Salafranca, J.A. Beltrán, and P. Roncalés. 2006. Stabilization of beef meat by a new active packaging containing natural antioxidants. Journal of Agriculture and Food Chemistry 52:5598-5605.

O’Grady, M.N., F.J. Monahan, J. Bailey, P. Allen, D.J. Buckley, and M.G. Keane. 2000. Colour-stabilising effect of muscle vitamin $\mathrm{E}$ in minced beef stored in high oxygen packs. Meat Science 50:73-80. 
Oussalah, M., S. Caillet, S. Salmiéri, L. Saucier, and M. Lacroix. 2004. Antimicrobial and antioxidant effects of milk protein-based film containing essential oils for the preservation of whole beef muscle. Journal of Agriculture and Food Chemistry 54:7840-7846.

Oussalah, M., S. Caillet, S. Salmiéri, L. Saucier, and M. Lacroix. 2006. Antimicrobial effects of alginate-based film containing essential oils for the preservation of whole beef muscle. Journal of Food Protection 69:2364-2369.

Pennington, J.A.T., and R.A. Fisher. 2009. Classification of fruits and vegetables. Journal of Food Composition and Analysis 22S:S23-S31.

Podsędek, A. 2007. Natural antioxidants and antioxidant capacity of Brassica vegetables: A review. Food Science and Technology 40:1-11.

Rota, M.C., A. Herrera, R.M. Martínez, J.A. Sotomayor, and M.J. Jordán. 2008. Antimicrobial activity and chemical composition of Thymus vulgaris, Thymus zygis and Thymus hyemalis essential oils. Food Control 19:681-687.

Shahidi, F., P.K. Janitha, and P. Wanasundara. 1992. Phenolic antioxidants. Critical Reviews in Food Science and Nutrition 32:67-102.

Shan, B., Y.Z.Cai, M.Sun, and H.Corke.2005. Antioxidant capacity of 26 spice extracts and characterization of their phenolic constituents. Journal of Agriculture and Food Chemistry 53:7749-7759.

Simitzis, P.E., S.G. Deligeorgis, J.A. Bizelis, A. Dardamani, I. Theodosiou, and K. Fegeros. 2008. Effect of dietary oregano oil supplementation on lamb meat characteristics. Meat Science 79:217-223.

Sivropoulou, A., E. Papanikolaou, C. Nikolaou, S. Kokkini, T. Lanaras, and M. Arsenakis. 1996. Antimicrobial and cytotoxic activities of Origanum essential oils. Journal of Agriculture and Food Chemistry 44:1202-1205.

Skandamis, P.N., and G.-J.E. Nychas. 2001. Effect of oregano essential oil on microbiological and physico-chemical attributes of minced meat stored in air and modified atmospheres. Journal of Applied Microbiology 91:1011-1022.

Skandamis, P.N., E. Tsigarida, and G.-J.E. Nychas. 2002. The effect of oregano essential oil on survival/death of Salmonella typhimurium in meat stored at $5^{\circ} \mathrm{C}$ under aerobic, VP/MAP conditions. Food Microbiology 19:97-103.

Su, L., J.-J. Yin, D. Charles, K. Zhou, J. Moore, and L. Yu. 2007. Total phenolic contents, chelating capacities, and radical-scavenging properties of black peppercorn, nutmeg, rosehip, cinnamon and oregano leaf. Food Chemistry 100:990-997.
Tabart, J., C. Kevers, J. Pincemail, J.-D. Defraigne, and J. Dommes. 2009. Comparative antioxidant capacities of phenolic compounds measured by various methods. Food Chemistry 113:1226-1233.

Tanabe, H., M. Yoshida, and N. Tomita. 2002. Comparison of the antioxidant activities of 22 commonly culinary herbs and spices on the lipid oxidation of pork meat. Animal Science Journal 73:389-393.

Tepe, B., D. Daferera, A. Sokmen, M. Sokmen, and M. Polissiou. 2005a. Antimicrobial and antioxidant activities of the essential oil and various extracts of Salvia tomentosa Miller (Lamiaceae). Food Chemistry 90:333-340.

Tepe, B., M. Sokmen, H.A. Akpulat, D. Daferera, M. Polissiou, and A. Sokmen. 2005b. Antioxidative activity of the essential oils of Thymus sipyleus subsp. sipyleus var. sipyleus and Thymus sipyleus subsp. sipyleus var. rosulans. Journal of Food Engineering 66:447-454.

Van Esch, G.J. 1986. Toxicology of tert-butylhydroquinone (TBHQ). Food Chemistry and Toxicology 24:10631065 .

Velioglu, Y.S., G. Mazza, L. Gao, and B.D. Oomah. 1998. Antioxidant activity and total phenolics in selected fruits, vegetables, and grain products. Journal of Agriculture and Food Chemistry 46:4113-4117.

Wheeler, T.L., M. Koohmaraie, and S.D. Schackelford. 1996. Effect of vitamin C concentration and coinjection with calcium chloride on beef retail display color. Journal of Animal Science 74:1846-1853.

Wojdylo, A., J. Oszmiański, and R Czemerys. 2007. Antioxidant activity and phenolic compounds in 32 selected herbs. Food Chemistry 105:940-949.

Yeum, K.-J., G. Beretta, N.I. Krinsky, R.M. Russell, and G. Aldini. 2009. Synergistic interactions of antioxidant nutrients in a biological model system. Nutrition 25:839-846.

Zheng, W., and S.Y. Wang. 2001. Antioxidant activity and phenolic compounds in selected herbs. Journal of the Agricultural and Food Chemistry 49:5165-5170.

Zheng, G., L. Xu, P. Wua, H. Xie, Y. Jiang, F. Chen, and X. Wei. 2009. Polyphenols from longan seeds and their radical-scavenging activity. Food Chemistry 116:433-436.

Zinoviadou, K.G., K.P. Koutsoumanis, and C.G. Biliaderis. 2009. Physico-chemical properties of whey protein isolate films containing oregano oil and their antimicrobial action against spoilage flora of fresh beef. Meat Science 82:338-345. 